\title{
Correlation of Virulence with Secretion in vitro of Three Wall-degrading Enzymes in Isolates of Sclerotinia fructigena Obtained after Mutagen Treatment
}

\author{
By HAZEL E. HOWELL* \\ University of Bristol, Long Ashton Research Station, \\ Bristol BSI 8 9AF
}

(Received 9 September 1974; revised 3 February 1975)

S U M MAR Y

Correlation and regression analyses were carried out between the virulence (expressed as growth rate in apple fruits) and the secretion in vitro of three host wall-degrading enzymes by I I 9 isolates of Sclerotinia fructigena, most of which had been obtained following exposure of conidia to $N$-methyl- $N^{\prime}$-nitro- $N$-nitrosoguanidine. Virulence was found to be significantly correlated $(P<0.01)$ with $\alpha$-L-arabinofuranosidase, but not with pectin esterase or, where enzyme interdependence had been statistically eliminated, with polygalacturonase. Approximately $35 \%$ of the total variability in virulence could be accounted for in terms of the three enzymes.

\section{INTRODUCTION}

The part played by wall-degrading enzymes in the pathogenicity of fungi and bacteria to higher plants is still not fully understood (Bateman \& Millar, I966; Wood, I967; Albersheim, Jones \& English, 1969). One experimental approach has been the attempted correlation of the virulence of a range of isolates with their ability to secrete specific wall-degrading enzymes (Howell, 1972). Both positive and negative correlations have been found; in some cases, different workers have reported opposite results for the same pathogen.

The fungus Sclerotinia fructigena, which causes the brown rot disease of apples, secretes a large number of wall-degrading enzymes in culture; most have been detected in vivo and may be involved in the pathogenicity of the fungus (Byrde et al. 1973). For 12 isolates of the related species Monilinia (Sclerotinia) fructicola, Hall (1972) showed a highly significant correlation $(r=0.88)$ between virulence and growth rate in vitro on pectin. On the other hand, in a comprehensive study Morrall, Duczek \& Sheard (1972) found no correlation between virulence to six hosts and pectolytic enzyme secretion by isolates of non-fruit-rotting Sclerotinia spp.

I have attempted to correlate virulence with the secretion of three wall-degrading enzymes by II 9 isolates of $S$. fructigena, mostly obtained following mutagen treatment. The term 'virulence' is used as defined by the Federation of British Plant Pathologists (1973), and implies a quantitative measure of the degree of pathogenicity of an isolate.

* Present address: I3 I, Sandon Road, Edgbaston, Birmingham BI 7 8HA. 


\section{METHODS}

Fungal culture. Sclerotinia fructigena Aderh. \& Ruhl. (ATCC26I06) was a monoconidial isolate from a spore suspension prepared from an infected apple fruit, of cultivar Cox's Orange Pippin. It was selected for its good growth rate in vitro and in vivo and its ability to sporulate in culture.

Media. Stock cultures of ATCC26I06 were maintained on potato-carrot agar (grated potato, $20 \mathrm{~g}$; grated carrot, $20 \mathrm{~g}$; agar, $20 \mathrm{~g}$; tap water, I 1). For sporulation or enzyme production, V-8 agar slopes or pectate-tartrate media respectively were used (Byrde \& Fielding, 1968). Growth rate in vitro was estimated on potato-dextrose agar (PDA) from Oxoid.

To preclude isolation of nutritionally deficient mutants following mutagen treatment, a minimal medium was used, containing (g/l): $\mathrm{NH}_{4} \mathrm{Cl}, 3 \cdot 0 ; \mathrm{MgSO}_{4} \cdot 7 \mathrm{H}_{2} \mathrm{O}, \mathrm{I} \cdot 5 ; \mathrm{KH}_{2} \mathrm{PO}_{4}$, 2.5; sucrose, 10.0; agar (Oxoid No. 3), 20.0. Where it was desired to limit colony size, as for initial isolation, the sucrose was reduced to $\mathrm{I} g$ and sorbose $(4 \mathrm{~g})$ included.

Mutagen treatments. These were done on twice-washed spore suspensions in sterile distilled water from V-8 cultures of ATCC26I06 approximately one week old. (i) Ultraviolet irradiation. Spore suspensions were placed in sterile quartz tubes closed with sterile corks. A glass-fronted box containing a mercury-vapour lamp, type T/M5/369E $\left(\lambda_{\max }\right.$ $240 \mathrm{~nm}$ ) (Thermal Syndicate Ltd, Wallsend, Newcastle), $150 \mathrm{~mm}$ distant from the rotating tube was used for irradiation for $45 \mathrm{~min}$, giving about $96 \%$ kill. The contents of each tube were poured into separate $100 \mathrm{ml}$ quantities of liquified sorbose agar at about $45^{\circ} \mathrm{C}$. Plates were poured immediately and incubated in darkness for $30 \mathrm{~h}$ to prevent photoreactivation. All discrete colonies were assumed to have developed from single spores and were transferred to slopes of minimal medium. (ii) $N$-methyl- $N^{\prime}$-nitro- $N$-nitrosoguanidine (NTG) treatment. Washed spores were exposed to NTG $(0.8 \mathrm{mM})$ for $2 \mathrm{~h}$ which gave about $95 \%$ kill. The spores were centrifuged $(500 \mathrm{~g}, 2 \mathrm{~min})$, washed four times with sterile water and either poured into minimal sorbose agar at $45{ }^{\circ} \mathrm{C}$, as above, or spread on the surface of that medium. Discrete colonies were transferred to minimal agar slopes.

Fungal growth rate estimation. (i) In vitro. Growth on solid media was assessed by inoculating at a central point each of 10 plates with a $4 \mathrm{~mm}$ disc, cut from the advancing edge of a colony on PDA, and placed fungus-side down on the surface. Cultures were incubated at $25^{\circ} \mathrm{C}$ in darkness. Colony growth was measured daily along two predetermined diameters at right-angles. (ii) In vivo. A thin flap of tissue on the 'equator' of an apple fruit was lifted with a sterile scalpel, and inoculated with a disc obtained as above. The flap was pressed down, and the fruit incubated in darkness at $25{ }^{\circ} \mathrm{C}$, with the open end of the flap pointing downwards. Measurements of the resulting rot were made along two diameters twice daily.

All growth rates were calculated by use of a standard parallel-line assay analysis. As this calculation was performed on diameters, the figures given are twice the radial growth rate. The $x$-intercept gave an indication of lag period.

Estimation of enzyme activities. $\alpha$-L-Arabinofuranosidase (AF) (EC.3.2.r.55) was assayed by the method described by Laborda, Fielding \& Byrde (1973) except that slightly different volumes were used. Activity was expressed relative to that of ATCC26I06 under identical conditions.

Polygalacturonase (PG) (EC. 3.2.I.15) was estimated by the agar plate method of Dingle, Reid \& Solomons (1953), incubating the plates overnight at $25^{\circ} \mathrm{C}$ and using 
Pectinol Io M (I mg/ml; Rohm \& Haas, Philadelphia, U.S.A.) as a standard. PG activity is expressed as $X-P+10$, where $X$ and $P$ were the mean ring diameters $(\mathrm{mm})$ for unknown and standard, respectively. This function is related to the logarithm of enzyme activity.

Pectin esterase (PE) (EC. 3.I.I.II) was estimated by the titration method, using the substrate mixture described by Smith (1958), adjusted to $\mathrm{pH} 5^{\circ} 0$, and a reaction time of $30 \mathrm{~min}$. Results were expressed as $\mathrm{ml}$ of $0.0 \mathrm{I} \mathrm{M}-\mathrm{NaOH} / \mathrm{h}$.

Design of main correlation experiment. This involved the estimation of four parameters: growth rate in vivo (as a measure of virulence), and in vitro secretion of $\mathrm{AF}, \mathrm{PG}$, and $\mathrm{PE}$. From an initial 859 isolates, isolates with growth rates in vitro so low as to preclude easy handling were eliminated. From the remainder, 139 isolates (ATCC26I06 itself, four derived from u.v. irradiation, I 9 from NTG treatment, and I 5 from conidia of ATCC26I06 which had had no mutagen treatment) were randomly selected.

Assays of the three enzymes were made on the filtrate from 7 -day-old cultures in pectate-tartrate medium $(5 \mathrm{ml})$ dispensed in specimen tubes $(7.5 \times 2.5 \mathrm{~cm})$, each seeded with a single $4 \mathrm{~mm}$ disc cut from the advancing edge of a colony on PDA. Incubation was carried out at $25{ }^{\circ} \mathrm{C}$ for 7 days on a reciprocal shaker (stroke $5 \mathrm{~cm}$; Ioo strokes $/ \mathrm{min}$ ).

From preliminary tests using ATCC26I06, the extent of variability was estimated and the required degree of replication calculated. Assays of AF and PE were accordingly done on 4 tubes/isolate, each tube being sampled twice; for PG, 6 tubes were each sampled three times. The means and standard errors for ATCC26ro6 for these assays were: PG, $10.89 \pm 0.86 \mathrm{~mm} ; \mathrm{PE}, 0.46 \pm 0.14 \mathrm{ml} 0.0 \mathrm{I} \mathrm{M}-\mathrm{NaOH} / \mathrm{h} ; \mathrm{AF}, 2.40 \pm 0.42 \Delta E_{403} / \mathrm{h}$. Laboratory temperature was used for the AF and PE assays. During the period when PE was assayed this was fairly constant, but varied while AF assays were performed. AF results were therefore expressed as percentages of those for ATCC26I06, in an attempt to eliminate the effects of uncontrolled temperature which seemed to be responsible for the greater part of the variation. However, the variations between control values were always small compared with the range found for the full set of isolates.

Apples, cultivar Bramley's Seedling, were used for the estimation of growth rate in vivo; they had been stored at $4{ }^{\circ} \mathrm{C}$ until a few days before use. The isolates were divided into three groups on the basis of their general level of enzyme secretion (which had by then been estimated), i.e. high, medium and low. Each apple was inoculated with one isolate from each group. Twenty replicates of the entire set of isolates were used, in a balanced incomplete block design; batches of apples were inoculated during a 9-week period. In a more detailed examination using ATCC26I06 and another isolate, some changes in growth rate over this period were demonstrated, presumably due to fruit senescence, but the layout was designed to minimize these changes as a source of variability.

For 20 isolates, growth rate was estimated in vitro also: it was expected that the use of a high glucose concentration in the PDA would repress pectolytic enzyme secretion. These estimations were done at the same time as the final replicate in vivo, and the same plates were used as the source of inoculum.

Statistical treatment of results. Correlations between data for growth rates and for enzyme secretion were examined. A comparison was made between the analysis of raw data and the use of hyperbolic transformations, which seemed justified for the enzymes if they were rate-limiting; for such a factor a given increase would seem likely to have a greater effect when it occurred from an initially low level than from an initially high level.

The transformations used in practice were: $\mathrm{I} / \mathrm{PG}, \mathrm{I} /(\mathrm{AF}+20)$, and $\mathrm{I} / \mathrm{PE}+0 \cdot 2$. The constants incorporated in the AF and PE transformations were selected empirically, to 
maximize the proportion of variability of growth rate in vivo which could be accounted for by the enzymes.

Three forms of correlation analysis were used: (i) multivariate correlation, in which it was assumed all variables, except the pair being examined, were independent; (ii) partial correlation, where the relation of each enzyme to growth rate was determined, eliminating the effects of the other two enzymes; (iii) multiple regression analysis, which attempted to explain variation in growth rate in vivo in terms of the three enzymes, allowing for possible correlations between the enzymes.

In the equation thus derived, the coefficient for each enzyme represented the difference in growth rate that would be associated with a given activity when the effects of the other two enzymes were eliminated. The equation also showed the proportion of the variability in growth rates which had been accounted for by the factors studied.

Throughout the Results, asterisks denote the levels of statistical significance; ${ }^{*} P<0.05$; ** $P<0.0 \mathrm{I} ;{ }^{* * *} P<0.00 \mathrm{I}$.

\section{RESULTS}

\section{Range of parameters recorded}

PG activities (corrected ring diameters) among the 139 isolates studied in detail varied from 5.34 to $17.06 \mathrm{~mm}$. Transforming these figures this represents a range from a 12 -fold reduction to a 17 -fold increase as compared with ATCC26I06. PE ranged from zero to $466 \%$ of the value for ATCC26106, and AF from 5 to $210 \%$. Secretion in vitro of a fourth enzyme [pectin lyase (EC. 4.2.2.10)] was unfortunately so variable in preliminary experiments with a few isolates that it was not routinely examined.

Growth rate in vivo ranged from 0.13 to $0.71 \mathrm{~mm} / \mathrm{h}$, representing 21 to $113 \%$ of that of ATCC26I06 $(0.63 \mathrm{~mm} / \mathrm{h})$. For 20 isolates, all NTG-derived, excessive variability was encountered in the data for growth rate in vivo and the analysis was therefore restricted to the remaining $1 \mathrm{I} 9$ isolates.

\section{Multivariate correlation}

Table I shows the simple correlation coefficients calculated from the data, both for the I 19 isolates for which growth rates in vivo were considered reliable and for the 20 isolates for which data for growth rate in vitro were also available (these 20 included three for which the data for growth in vivo was highly variable). For the latter group of 20 , correlations were in general less significant, and no significant correlation was obtained between growth rates in vitro and in vivo. The larger analysis gave evidence of a correlation between AF and PG, and between each and growth rate in vivo, also between PE and PG or AF.

When untransformed data for the II9 isolates were analysed, only PG-AF, PG-PE, and $\mathrm{AF}$-growth in vivo, were significantly correlated.

No significant correlation was found between the lag period ( $x$-axis intercept) in vivo and transformed enzyme data.

\section{Partial correlation}

As already mentioned, this analysis was done to eliminate the effects of any interdependence of enzyme data. Table 2 summarizes the results obtained and gives strong evidence that virulence, in terms of growth rate in vivo, is correlated with AF secretion in vitro, but is not correlated with either of the other two enzymes. Presumably the apparent relationship between growth rate in vivo and PG secretion indicated in Table I arose from the PG-AF interdependence also shown there. PE secretion showed no significant correlation, but tended to be associated with less growth rather than more. 
Table I. Simple correlation coefficients between growth rates and parameters for three extracellular enzymes of $S$. fructigena

For units, see text. Asterisks denote statistical significance: *, $P<0.05$; $^{* *}, P<0.01$; ${ }^{* * *}, P<0.001$. ND, Not done.

$\begin{array}{cccccc}\begin{array}{c}\text { No. of } \\ \text { isolates } \\ \text { examined }\end{array} & \frac{\mathrm{I}}{\mathrm{Parameter}} & \mathrm{AF}+20 & \frac{\mathrm{I}}{\mathrm{PE}+0.2} & \overbrace{\text { in vivo }}^{\text {Growth }} \\ { }_{119} & \frac{\mathrm{I}}{\mathrm{PG}} & 0.45^{* * *} & 0.33^{* * *} & -0.31^{* * *} & \mathrm{ND} \\ & \frac{\mathrm{I}}{\mathrm{AF}+20} & - & 0.38^{* * *} & -0.53^{* * *} & \mathrm{ND} \\ & \frac{\mathrm{I}}{\mathrm{PE}+0.2} & - & - & -0.09 & \mathrm{ND} \\ & \frac{\mathrm{I}}{\mathrm{PG}} & 0.30 & 0.32 & -0.25 & -0.44^{*} \\ & \frac{1}{\mathrm{AF}+20} & - & 0.53^{*} & -0.63^{* *} & -0.10 \\ & \frac{\mathrm{I}}{\mathrm{PE}+0.2} & - & - & -0.09 & 0.09 \\ & \begin{array}{l}\text { Growth } \\ \text { in vivo }\end{array} & - & - & - & 0.3 \mathrm{I}\end{array}$

Table 2. Partial correlation coefficients between growth rates and parameters for three extracellular enzymes of $S$. fructigena

Negative correlation coefficients for reciprocal functions of enzymes indicate positive correlation for untransformed values. Asterisks denote statistical significance: ${ }^{*}, P<0.05{ }^{* *}, P<0.01$.

$\begin{array}{cccc}\text { Enzyme parameter } & \begin{array}{c}\text { Growth of } \\ \text { in vivo } \\ \text { isolates }\end{array} & \overbrace{\text { in vivo }}^{\text {Growth of 20 isolates }} \\ \frac{\mathrm{I}}{\mathrm{PG}} & -0.13 & -0.18 & \text { in vitro } \\ \frac{\mathrm{I}}{\mathrm{AF}+20} & -0.49^{* *} & -0.67^{*} & -0.55^{*} \\ \frac{\mathrm{I}}{\mathrm{PE}+0.2} & 0.16 & 0.39 & -0.26 \\ & & & 0.42\end{array}$

Multiple regression analysis

This was calculated using transformed enzyme values against growth rate in vivo (y) or against reciprocal of growth rate $(\mathrm{I} / y)$. The equations obtained (a further sign change accompanies the use of the reciprocal for growth) were:

and

$$
y=0.726-\frac{0.93 \mathrm{I}}{\mathrm{PG}}-\frac{\mathrm{I} 2 \cdot 8^{* *}}{\mathrm{AF}+20}+\frac{0.034}{\mathrm{PE}+0.2}
$$

$$
\frac{\mathrm{I}}{y}=0.559+\frac{6 \cdot 39}{\mathrm{PG}}+\frac{\mathrm{II} 3 \cdot 7^{* *}}{\mathrm{AF}+20}-\frac{0 \cdot 235}{\mathrm{PE}+0 \cdot 2}
$$


This analysis thus confirms that AF is the only enzyme examined which shows a significant relationship with growth rate in vivo.

In the two equations, the proportions of the total variability in virulence accounted for by variation in enzyme values were 30.9 and $37.0 \%$, respectively, of which the major contribution clearly came from AF.

Full details of the results have been lodged with the British Lending Library, Boston Spa, Yorkshire, as Supplementary Publication No. SUP 28002 (6 pp.). Copies may be obtained from the BLL on demand. Requests should be accompanied by prepaid coupons (held by many university and technical libraries, and by the British Council) or by a cheque for $25 \mathrm{p}$ (65p to Europe, $75 \mathrm{p}$ elsewhere) per copy.

\section{DISCUSSION}

Attempted correlations between the virulence of fungi or bacteria and their ability to secrete wall-degrading enzymes are difficult to interpret. Conclusions have sometimes been based on very small numbers of isolates, and a positive correlation, where obtained, is no proof of cause and effect. Secretion of pectolytic enzymes in vitro is also very easily modified by the growth medium used (Bateman \& Millar, 1966).

Negative results may be open to several other criticisms: (i) published correlation data rarely take account of all the enzymes known to be secreted by fungi and bacteria; (ii) different species, or even genera, of the pathogen have sometimes been used, where many factors other than wall-degrading enzyme secretion would be variable; (iii) the heritability of the parameters has generally not been examined; unless this is high, changes could occur during the period of the tests, especially if repeated transfers were involved.

The present study attempted to meet some of these objections. Thus to meet objection (i), an enzyme (AF) attacking neutral sugar polymers was included, together with two (PG and PE) attacking polyuronide; it was unfortunate that, for reasons mentioned above, pectin lyase could not be included. Objection (ii) was partially overcome by the use of closely related isolates. However, because of the multinucleate conidia and likely heterokaryotic nature of S. fructigena (Hoffmann, 1970, 1972; Howell, 1972), other factors besides those examined were probably also variable, though this variability is likely to be less than if unrelated isolates had been used. Objection (iii) was partially met by the demonstration (Howell, 1972) that the variability of the untreated progeny of two isolates for PG, and of one isolate for the other parameters, was considerably less than the differences between the mutagen-treated isolates that were analysed.

Of the two mutagens used, NTG appeared much more effective in producing isolates with widely varying wall-degrading enzyme activities. One of the isolates obtained after NTG treatment showed a I7-fold increase in PG secretion, and may be useful in studies on this enzyme.

The analysis supports the view (Byrde et al. 1973) that secretion of wall-degrading enzymes is involved in the pathogenicity of $S$. fructigena to apple fruit: the multiple regression was particularly valuable in quantifying the degree of involvement, estimated to be about $35 \%$ for the enzymes examined. Of these, and within the range of activities recorded, AF secretion was the parameter most closely correlated with virulence, and the apparent involvement of PG in the 'simple' correlation was seen to stem from its own association with AF. This association may reflect some common factor in the control mechanisms, some evidence for the existence of which was obtained in enzyme induction studies by Archer (1973). PE, in contrast, did not appear to be involved (cf. Volkova, 1971, working with Pseudomonas tabaci). 
Table 2 shows a positive correlation between PG and growth in vitro. Such correlations were expected because the amount of a constitutive or induced enzyme secreted would seem likely to be related to the general vigour of the isolate. The analysis of selected strains for growth rate in vitro confirmed that such effects were not responsible for any correlations found with results in vivo.

At first sight, the AF-virulence correlation is surprising. Unlike PG and pectin lyase, the AF of $S$. fructigena does not have readily detectable physiological effects, for it causes neither tissue maceration (Byrde \& Fielding, 1968) nor cell leakage (Byrde et al. 1973). This lack of activity is probably due, at least in part, to the enzyme's 'terminal' hydrolysis mechanism - which would result in a slower decrease in polymer size than that caused by random cleavage.

Three hypotheses to account for the observed correlation of AF with virulence seem worthy of consideration: (i) Before host cell leakage occurs, the arabinose liberated could serve as carbon source for the advancing hyphae.

(ii) Some fungal endopolygalacturonases can be inhibited by lectins present in cell walls (Albersheim \& Anderson, 1971). A lectin from potato was found to contain a very high proportion of arabinose units in the polysaccharide component of the glycoprotein (Allen \& Neuberger, 1973). Such units could be hydrolysed by AF, so lessening or eliminating inhibitory effects on other extracellular fungal enzymes, or any 'recognition' function the lectin might possess. Knee (1975) detected in apple fruit the presence of wall glycoproteins, with typical hydroxyproline-arabinoside linkages, that were susceptible to very slow attack by AF.

Another association, apparently of a different kind, between pathogen virulence and changes in arabinose-containing polymers in the host was reported by Tatareau \& Auriol (1972) and Touzé (1973), working with Colletotrichum lagenarium attacking Cucumis melo. A significant increase in polymer-bound arabinose was noted following infection, the extent of the increase being greater with the more virulent isolates of the pathogen.

(iii) The possibility cannot be discounted that AF is not itself directly involved, but that virulence is primarily governed by an unknown factor, with which AF is sufficiently associated (e.g. through a joint control mechanism) to account for the observed AFvirulence correlation. Such a mechanism was postulated for the lack of mannanase and xylanase in cellulase-negative mutants of Polyporus adustus (Eriksson \& Goodell, 1974). For S. fructigena, if another enzyme is implicated it is clearly more closely associated with $\mathrm{AF}$ than with PG or PE. The cross-induction by arabinose of galactanase and $\beta$-galactosidase secretion by two plant pathogenic fungi (Cooper \& Wood, 1973) may be relevant. There are indications (Table 2) that linear growth rate in vitro is not the factor, as was also found by Barker \& Walker (I962) for another system.

The correlation took no account of subsequent work showing that extracellular AF exists in two isoenzymic forms of differing pI values and molecular weights (Laborda et al. 1973) and immunochemically distinct from each other (Hislop et al. 1974). Nevertheless, the results are most easily interpreted as pointing to a role, albeit unexpected, in fungal pathogenesis for AF, an enzyme not previously examined in correlation experiments. Its status in other host-pathogen combinations, e.g. legume diseases (Fuchs, Jobson \& Wonts, 1965), seems worthy of further study. 
I thank Drs L. C. Frost and C. J. Grant for helpful discussion and use of equipment, Mr C. R. Baines, Miss M. Holgate and Miss E. P. Bennett for statistical advice, Mr A. H. Fielding for AF substrate, Mrs C. H. Perry for technical assistance, and Dr R. J. W. Byrde for helpful discussion, encouragement and assistance in preparation of the typescript. The work was supported by a Studentship from the MAFF.

\section{REFERENCES}

Albersheim, P. \& Anderson, A. (1971). Host-pathogen interactions. III. Proteins from plant cell walls inhibit polygalacturonases secreted by plant pathogens. Proceedings of the National Academy of Sciences of the United States of America 68, 1815-1819.

Albersheim, P., Jones, T. M. \& English, P. D. (1969). The cell wall in relation to infective processes. Annual Review of Phytopathology 7, 17 I-194.

Allen, A. K. \& Neuberger, A. (1973). The purification and properties of the lectin from potato tubers, a hydroxyproline-containing glycoprotein. Biochemical Journal 135, 307-3I4.

ArCher, S. A. (1973). Physiological aspects of brown rot of apple. Ph.D. thesis, University of Bristol.

BARKer, K. R. \& WALker, J. C. (1962). Relationship of pectolytic and cellulytic enzyme production by strains of Pellicularia filamentosa to their pathogenicity. Phytopathology 52, 111 19-1 128.

Bateman, D. F. \& Millar, R. L. (1966). Pectic enzymes in tissue degradation. Annual Review of Phytopathology 4, II9-I46.

BYrde, R. J. W. \& Fielding, A. H. (I968). Pectin methyl-trans-eliminase as the maceration factor of Sclerotinia fructigena and its significance in brown rot of apple. Journal of General Microbiology 52, 287-297.

Byrde, R. J. W., Fielding, A. H., Archer, S. A. \& Davies, E. (1973). The role of extracellular enzymes in the rotting of fruit tissue by Sclerotinia fructigena. In Fungal Pathogenicity and the Plant's Response, pp. 39-52. Edited by R. J. W. Byrde and C. V. Cutting. London: Academic Press.

COOPER, R. M. \& WOOD, R. K. S. (I973). Induction of synthesis of extracellular cell-wall degrading enzymes in vascular wilt fungi. Nature, London 246, 309-31 I.

Dingle, J., Reid, W. W. \& Solomons, G. L. (I953). The enzymic degradation of pectin and other polysaccharides. II. Application of the 'cup-plate' assay to the estimation of enzymes. Journal of Science of Food and Agriculture 4, I49-1 55.

Eriksson, K.-E. \& Goodell, E. W. (1974). Pleiotropic mutants of the wood-rotting fungus Polyporus adustus lacking cellulase, mannanase and xylanase. Canadian Journal of Microbiology 20, 37I-378.

Federation of British Plant Pathologists (1973). A Guide to the Use of Terms in Plant Pathology. Phytopathological Papers No. 17. Kew, Surrey: Commonwealth Mycological Institute.

Fuchs, A., Jobson, J. A. \& Wonts, W. N. (1965). Arabanases in phytopathogenic fungi. Nature, London 206, 714-715.

Hall, R. (1972). Pathogenicity of Monilinia fructicola. III. Factors influencing lesion expansion. Phytopathologische Zeitschrift 73, 27-38.

Hislop, E. C., Shellis, C., Fielding, A. H., Bourne, F. J. \& Chidlow, J. W. (1974). Antisera produced to purified extracellular pectolytic enzymes from Sclerotinia fructigena. Journal of General Microbiology 83, $135-143$.

Hoffmann, G. M. (1970). Kernverhältnisse bei Monilia fructigena und M. laxa. Phytopathologische Zeitschrift 68, I43-154.

HoffmanN, G. M. (1972). Heterokaryose bei Wildstämmen von Monilinia fructigena. Phytopathologische Zeitschrift 73, 326-340.

Howell, H. E. (1972). Production of extracellular enzymes by Sclerotinia fructigena Aderh. \& Ruhl. Some observations on their importance in pathogenicity and on their inheritance. Ph.D. thesis, University of Bristol.

Knee, M. (1975). Soluble and wall-bound glycoproteins of apple fruit tissue. Phytochemistry (in the Press).

LABORda, F., Fielding, A. H. \& Byrde, R. J. W. (1973). Extra- and intra-cellular $\alpha$-L-arabinofuranosidase of Sclerotinia fructigena. Journal of General Microbiology 79, 32I-329.

Morrall, R. A. A., Duczek, L. J. \& Sheard, J. W. (1972). Variations and correlations with and between morphology, pathogenicity and pectolytic enzyme activity in Sclerotinia from Saskatchewan. Canadian Journal of Botany $\mathbf{5 0}, 767-786$.

SмIтH, W. K. (I958). A survey of the production of pectic enzymes by plant pathogenic and other bacteria. Journal of General Microbiology 18, 33-4I. 
Tatareau, J.-C. \& Auriol, P. (1972). Correlation entre la virulence de Colletotrichum lagenarium et son aptitude à degrader les polyosides des parois cellulaires d'un hôte sensible. Comptes rendus hebdomadaire des séances de l'Academie des sciences 274, $1304-1306$.

TouzÉ, A. (1973). Anthracnose fungus virulence and changes induced in host cell wall. Abstracts of Papers, 2nd International Congress of Plant Pathology (held at Minneapolis, U.S.A.), No. or 15.

Volkova, V. P. (197I). Polygalacturonase activity of Pseudomonas tabaci. Mikrobiologicheskii zhurnal 33, II $2-I 13$.

Wood, R. K. S. (1967). Physiological Plant Pathology. Oxford and Edinburgh: Blackwell Scientific Publications. 